\title{
NONLINEAR BEHAVIOR OF CANTILEVER GIRDERS WITH CORRUGATED STEEL WEBS
}

\section{F.M.El-Amin; M.F. Abdel-Khalek; M.M.Ahmed and S.R.Gad}

Civil Engineering Department, Faculty of Engineering, Assuit University, Assiut, Egypt

\section{(Received July 26, 2008 Accepted October 25, 2008)}

The shear behavior of cantilever girders with corrugated steel webs has been investigated here experimentally and analytically. Three cantilever beams with corrugated steel webs were tested to failure under shear; the failure was due to buckling of the web. Computer program COSMOS/M 2.8 was used to perform nonlinear analysis to the models of the test specimens to determine ultimate load of these girders. Proposed interaction equation, which based on local buckling of the corrugation fold as isotropic flat plates, global buckling of the entire web panels as an orthotropic plate, and steel yielding of the web is presented. It was noted from the experimental and the analytical results that buckling of the web is local or global for the coarse or dense corrugation, respectively. Comparisons between the results from the proposed equation, the finiteelement analysis, and the tests are satisfactory.

KEYWORDS: experimental tests, finite element method, cantilever girders, corrugated steel webs, global buckling mode, local buckling, nonlinear analysis.

\section{NOMENCLUTURE}

$\begin{array}{ll}a & =\text { cantilever span. } \\ h_{w} & =\text { web height. } \\ t_{w} & =\text { web thickness. } \\ b_{f l} & =\text { width of flange. } \\ t_{f l} & =\text { thickness of flange. } \\ b & =\text { width of horizontal fold of } \\ & \text { corrugation } \\ i & =\text { width of inclined fold of } \\ c & \text { corrugation. } \\ & =\text { horizontal length of one } \\ & \text { corrugation. }\end{array}$

$s \quad=$ unfolded length of one corrugation.

$\alpha \quad=$ angle of corrugation.

$f_{\mathrm{y}} \quad=$ yield stress of web material.

$f_{\mathrm{fl}}=$ yield stress of flange material.

$\tau_{y} \quad=$ shear yield stress of web material.

$\tau_{c r, l}=$ local shear buckling.

$\tau_{c r, g}=$ global shear buckling .

$\tau_{c r, i}=$ interactive shear buckling. 


\section{INTRODUCTION}

Corrugated steel webs have been recently introduced to replace the stiffened steel plates of plate/box girder to allow the use of thin plates without stiffeners for use in building and bridges, and to increases the out of plane stiffness and buckling strength of girders.

The idea of using corrugated webs was first introduced for steel beams in buildings with web thickness ranging between 2 and $5 \mathrm{~mm}$, and with web height to thickness ratio between 150 and 260. Using corrugated webs for bridge girders allows the web height to thickness ratio to reach 400 . Typical thicknesses of corrugated web plates used lately in bridges were 8 to $12 \mathrm{~mm}$ and with web height to thickness ratio between 220 to 375 . Recently in Japan the web height to thickness ratio used in bridges is about 445 .

Several previous studies had been concerned on steel girders with corrugated webs. Most of these about the shear and bending behavior of simply supported beams.

Bleich [1] derived a simplified equation to calculate critical shear stress for rectangular plate under shear load.

Basler [2] investigated the shear strength of plate girders and presented formula to calculate critical shear stress for rectangular plate under shear load.

Easley and McFarland [3], [6] discussed three different formulae for elastic buckling loads of light-gauge corrugated metal shear diaphragms subjected to in plane shear loads; Easley-McFarland buckling formula, Bergman-Reissner[4] buckling formula and Hlavacek [5] buckling formula. They analyzed the three different buckling formulae, and noted that the Bergman-Reissner buckling formula was the most rigorous of the three, and also Easley - McFarland formula was in agreement with Bergman - Reissner buckling formula and both of them give lower buckling load than Hlavacek formulas which had 20\% difference from the test result.

Galambos [7] presented an estimated equation to calculate elastic critical shear stress of corrugated webs.

Bergfelt and Leiva-Aravena [8] presented an equation based on the experimental analyses, used to calculate the critical stress due to the interaction between local and global buckling modes.

Hamilton [9] had performed 42 tests on 21 simply supported beams to failure under shear load to investigate the effects of web thickness, aspect ratio of shear span, and the corrugation profile dimensions on the shear buckling behavior of the corrugated steel webs. He noted that all the beams tested failed due to buckling of the corrugated webs. Some beams failed due to local buckling and the other failed due to global buckling depending on corrugation profile dimension.

Elgaaly et al. [10] had studied the shear strength of beams with corrugated steel webs. They modeled the test specimens performed by Hamilton using finite elements and they performed nonlinear analysis using computer program ABAQUS to calculate shear buckling load for these specimens. They noted that the average ratio between analytical and experimental buckling loads was 1.15 . The primary reason why the analytical results are higher than the experimental is the presence of unavoidable imperfections in the webs of the test specimens. They noted from the experimental and analytical results that the shear is carried by the web and controlled by buckling; which is local or global for the coarse or dense corrugation, respectively .They suggested 
buckling formulae for corrugated steel webs which are based on local buckling of the corrugation folds as isotropic flat plates or global buckling of the entire web panel as an orthotropic plate. They had recommended that the local and global buckling values are calculated and the smaller value controlled the failure. Finally they made comparisons between the results from the formulae, the finite element analysis, and the tests; they noted that these comparisons are satisfactory.

Elgaaly et al. [11] presented numerical and experimental investigations on the flexural strength of steel beams with corrugated webs. Simply supported beams with corrugated webs were tested to failure under uniform bending. Failures were sudden and due to the vertical buckling of the compression flange until reach to the yield stress in the flange then a vertical buckling of the flange into the web. They mainly concluded that the contribution of corrugated web to the ultimate moment capacity of the beam is negligible. Thus the ultimate moment capacity will be based on the flange yield stress. The stresses in the web due to bending are equal to zero except for very close to flanges where the web is restrained. The flanges provide the boundary restraints for the corrugated web which ranges between simply supported for girders with steel flanges and clamped for girders with concrete flanges.

Sayed [14] investigated shear behavior of corrugated steel webs. He proposed an interaction equation which considered the different failure criteria including steel yielding. He performed numerical analysis for simply supported steel girders with corrugated steel webs under shear load using finite element technique. He performed a linear elastic analysis to assess the theoretical buckling modes. Also he performed a nonlinear finite element model to verify the proposed interaction equation. The results obtained from the numerical analysis were found to be in a good agreement with the theoretical prediction obtained using the critical stress equations and the proposed interaction equations. Also he used the proposed interaction equation to investigate the effect of the corrugated plate geometric characteristics on the failure mode. He found that the panel width of corrugation had the most significant effect on the buckling modes.

In this paper we study the shear behavior of cantilever girders with corrugated webs experimentally and analytically. Buckling formulae for different buckling modes which may appear in corrugated plates will be investigated here. The interaction between the yield failure criterion and these buckling modes will be presented. Proposed interaction equation which considers different failure criteria including the shear yielding of corrugated steel webs will be presented. Also the comparisons between the results obtained from test, finite element, and proposed interaction equation are presented.

\section{SHEAR FAILURE MODES OF CORRUGATED STEEL WEBS}

\section{1- Theoretical Equations}

Shear failure of corrugated steel webs may occur due to shear yielding, buckling or interactively between yielding and buckling. 
$\mathrm{c}$

Trapezoidal corrugation

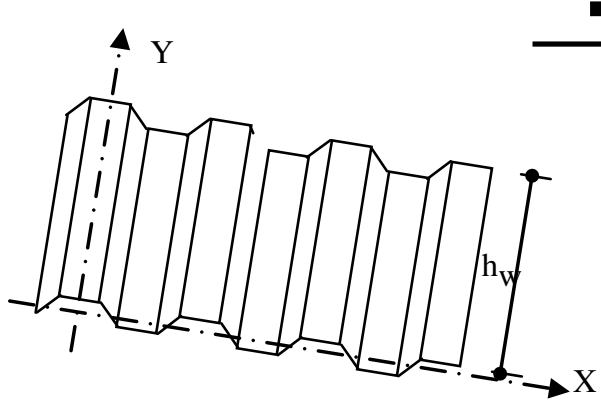

Coordinate system

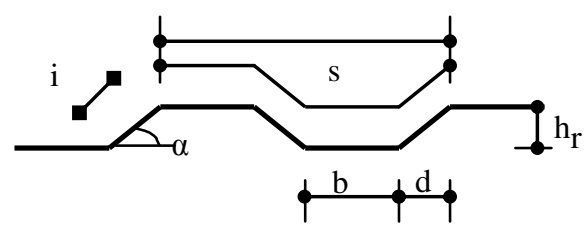

Plate thickness $=\mathrm{t}_{\mathrm{w}}$

$\mathrm{S}=2(\mathrm{~b}+\mathrm{d} / \cos \alpha)$ $=2(b+i)$

$\mathrm{h}_{\mathrm{r}}=\mathrm{d} \tan \alpha$ $\mathrm{i}=\mathrm{d} / \cos \alpha$

Geometric properties

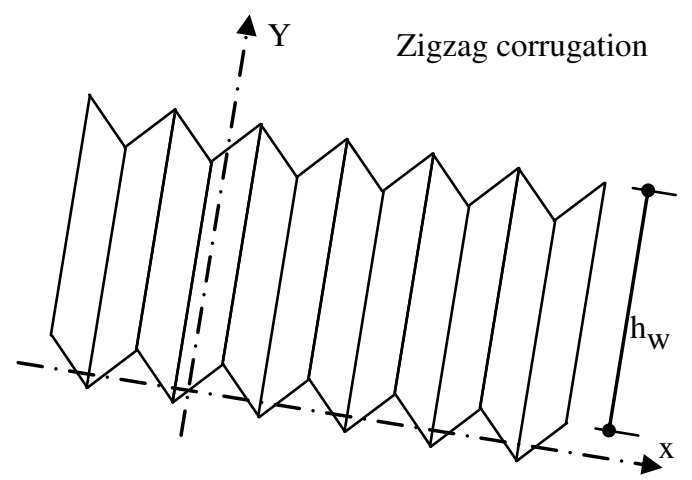

Coordinate system

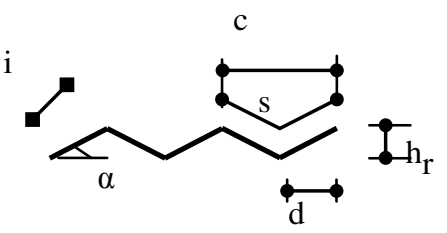

Plate thickness $=\mathrm{t}_{\mathrm{W}}$

$\mathrm{S}=2(\mathrm{~d} / \cos \alpha)$ $=2 \mathrm{i}$ $\mathrm{h}_{\mathrm{r}}=\mathrm{d} \tan \alpha$

Geometric properties

Fig.1: Corrugated plates with trapezoidal and zigzag corrugation profiles

\section{i- Steel yielding of Web}

The shear stress which causes an element of corrugated web to yield when it is subjected to pure shear stress state can be determined using von mises yield criterion with $f y$ being the yield strength of the steel as,

$$
\tau_{y}=\frac{f_{y}}{\sqrt{3}}
$$

Where $f y$ is the yield strength of the steel.

\section{ii- Stability of Corrugated Web}

Two buckling modes are associated with corrugated steel web; local and global buckling. 


\section{Local buckling mode}

Corresponds to the instability of a steel panel simply supported between two folds, corrugated web in this mode of failure acts as a series of flat plate sub panels that mutually support each other along their vertical (longer) edges and are supported by the flanges at their horizontal (shorter) edges. These flat plate sub panels are subjected to shear, the elastic buckling stress considering these plate as isotropic plates is given by Galambos [7].

$$
\tau_{c r, l}=k_{s} \frac{\pi^{2} E}{\left(1-v^{2}\right)}\left(\frac{t}{b}\right)^{2}
$$

Where $t_{w}$ is the corrugated web plate thickness, $b$ is the bigger of the horizontal or inclined flat plate sub panel width, $\mathrm{E}$ and $v$ is the Young's modulus and the Poisson's ratio for the steel respectively and $\mathrm{k}_{\mathrm{S}}$ is shear buckling coefficient for the local buckling mode. The shear buckling coefficient is function of boundary restraints and the panel aspect ratio $\mathrm{b} / \mathrm{h}_{\mathrm{W}}$ where $\mathrm{h}_{\mathrm{W}}=$ web height.

$$
\begin{aligned}
& k_{s}=5.34+4\left(\frac{b}{h_{w}}\right)^{2}, \text { for all edges simply supported } \\
& k_{s}=8.98+5.6\left(\frac{b}{h_{w}}\right)^{2}, \text { for all edges clamped } \\
& k_{s}=5.34+2.31\left(\frac{b}{h_{w}}\right)-3.44\left(\frac{b}{h_{w}}\right)^{2}+8.39\left(\frac{b}{h_{w}}\right)^{3},
\end{aligned}
$$

\section{Global buckling mode}

It is characterized by diagonal buckling over several corrugation panels. This failure mode is typical for dense corrugation. When global buckling occurs, the buckling stress can be calculated using the orthotropic-plate buckling theory. The global elastic buckling stress can be calculated from Galambos, [7]:

$$
\tau_{c r, g}=k_{g} \frac{D_{x}^{0.25} D_{y}^{0.75}}{t h_{w}^{2}}
$$

Where $k_{\mathrm{g}}$ is global shear buckling coefficient depends solely on the web top and bottom constrains: $k_{\mathrm{g}}=36$ for steel flanges and $=68.4$ for composite flanges (Elgaaly et al. [10]).

The factors $\mathrm{D}_{\mathrm{X}}$ and $\mathrm{Dy}$ are the flexural stiffness per unit corrugation about the $\mathrm{x}$-and y-axes respectively (Fig.1). These factors are defined as follows:

$$
D_{x}=\frac{E I_{x}}{c}
$$




$$
D_{Y}=\frac{c}{s} \frac{E t_{w}^{3}}{12}
$$

For trapezoidal corrugation profile:

$$
\begin{aligned}
& D_{Y}=\frac{c}{s} \frac{E t_{w}^{3}}{12}=\left(\frac{b+d}{b+d \sec \alpha}\right) \frac{E t_{w}^{3}}{12} \\
& D_{x}=\frac{E I_{x}}{c}=\left(\frac{E}{b+d}\right)\left(\frac{b t_{w}(d \tan \alpha)^{3}}{4}+\frac{t_{w}(d \tan \alpha)^{3}}{12 \sin \alpha}\right)
\end{aligned}
$$

For zigzag corrugation profile:

$$
\begin{aligned}
& D_{Y}=\frac{c}{s} \frac{E \boldsymbol{t}_{w}^{3}}{12}=(\cos \alpha) \frac{E \boldsymbol{t}_{w}^{3}}{12} \\
& D_{x}=\frac{E \boldsymbol{I}_{x}}{c}=\left(\frac{E}{d}\right)\left(\frac{\boldsymbol{t}_{w}(d \tan \alpha)^{3}}{12 \sin \alpha}\right)
\end{aligned}
$$

Where $\mathrm{I}_{\mathrm{X}}$ is the second moment of area of "wavelength" of the web, $\mathrm{c}=$ the wave projection length, $\mathrm{s}=$ the actual wave length, $\mathrm{t}_{\mathrm{w}}=$ the web thickness, $\mathrm{b}=$ the panel width, $\mathrm{d}=$ the horizontal projection of the inclined panel width, $\alpha=$ the corrugation angle, and $\mathrm{d} \tan \alpha=$ the corrugation depth; as shown in Fig-(1)

\section{2- Interaction between Failure Modes}

The following equation can be used to calculate the interaction between the buckling modes described earlier; which based on the experimental analyses performed by Bergfelt and Leiva-Aravena[8];the critical stress due to the interaction between local and global buckling modes $\left(\tau_{\mathrm{cr}, \mathrm{i}}\right)$ had given as,

$$
\frac{1}{\tau_{c r, i}}=\frac{1}{\tau_{c r, l}}+\frac{1}{\tau_{c r, g}}
$$

This equation doesn't consider the steel yielding failure criterion and its interaction with the other buckling failure criteria.

If the critical shear stress calculated from any mode exceeds $(0.8 \tau y)$ inelastic buckling will occur and the following equation can be used (Elgaaly et al. [10]; Galambos [7]) to calculate the inelastic critical stress $\tau_{\mathrm{cr} \text {, in }}$ for both local and global buckling modes:

For $\tau_{\mathrm{cr}, 1}>0.8 \tau_{\mathrm{y}}$ :

$$
\tau_{c r, i n, l}=\sqrt{0.8 \tau_{c r, l}} \cdot \tau_{y}, \text {, Where } \tau_{\mathrm{cr}, \text { in }, 1} \leq \tau_{\mathrm{y}}
$$

For $\tau \mathrm{cr}, \mathrm{g}>0.8 \tau \mathrm{y} \quad$ :

$$
\tau_{c r, i n, g}=\sqrt{0.8 \tau_{c r, g}} \cdot \tau_{y}, \text { Where } \tau_{\mathrm{cr}, \text { in }, \mathrm{g}} \leq \tau_{\mathrm{y}}
$$




\section{3- Proposed Interaction Equation}

Another interaction equation which includes all failure criteria (steel yielding, local and global buckling stress) has been proposed by El-Metwally and Loov ( [12], [13]):

$$
\frac{1}{\tau_{c r, i}^{n}}=\frac{1}{\tau_{c r, l}^{n}}+\frac{1}{\tau_{c r, g}^{n}}+\frac{1}{\tau_{y}^{n}}
$$

Where $\tau_{\mathrm{y}}, \tau_{\mathrm{cr}, \mathrm{i}}$ and $\tau_{\mathrm{cr}, \mathrm{g}}$ are defined by equations 1,2 and 3 , respectively. Equation (16) gives the least value of the limits of the right-hand side as the maximum limit of the resulting $\tau_{\mathrm{cr}, \mathrm{i}}$ in the left-hand side, regardless the exponent $\mathrm{n}$ value .A low value for $n($ e.g. $n=1)$ gives $\tau_{\mathrm{cr}, \mathrm{i}}$ less than the least of the three limits. On the other hand, higher values for $\mathrm{n}$ gives $\tau_{\mathrm{cr}, \mathrm{i}}$ close to the least of the three limits.

\section{LABORATORY SPECIMENS}

Three tests performed on three over hanged cantilever steel girders with corrugated webs in the steel construction laboratory, Faculty of Engineering, Assuit University. Girders have been manufactured by local steel fabricator; the web depth is $250 \mathrm{~mm}$ (9.84 in) and the thickness of web in all girders is $1 \mathrm{~mm}$ (web height to thickness ratio equal 250 for all specimens). Girders consisted of two equal cantilever (233.2 260) $\mathrm{mm}$ lengths. The flange width in all girders is $100 \mathrm{~mm}$ and thickness is $8.8 \mathrm{~mm}$ in one girder and $6 \mathrm{~mm}$ in the two other, as shown in Table 1. Three corrugation profiles shown in Table 2 were used for these three girders, two trapezoidal, $\mathrm{t}_{\mathrm{z} 1}, \mathrm{t}_{\mathrm{z} 2}$ and the third is triangular $\mathrm{t}_{\mathrm{r} 1}$. The two beams $\mathrm{t}_{\mathrm{z} 1}$ and $\mathrm{t}_{\mathrm{z} 2}$ have the same width $30 \mathrm{~mm}$ of horizontal and inclined fold, with angles of corrugation equal 37 and 60 degrees respectively. The third beam $t_{r 1}$ has $30 \mathrm{~mm}$ width of the inclined fold with 45 degrees angle of corrugation.

Four steel plate stiffeners $(250 \times 100 \times 10) \mathrm{mm}$ were used in every girder; one over each support and one at the each end. Webs in all girders were welded continuously to flanges and vertical stiffeners using two side fillet welds. The stiffener plates have had fillet weld to the flange plates from two sides. The size of the weld for connecting built up section and end connecting plates is taken according to the Egyptian code of practice for steel constructions and bridges [16C: $\mathrm{New}$
[New Folderlmasterljersc modif.doc].Careful procedures of welding were followed to avoid the initial imperfection of the web as can as possible. All girders were over hanged cantilever and two equal concentrated loads were applied at the two ends of girders; one load at each end as shown in Fig. (2). To determine the mechanical properties of the steel specimens, six standard tension coupons were cut from steel of specimens; three from flange steel and three from web steel. The coupons were prepared and tested according to the Egyptians standard codes no 76 for tensile test of metals, having a gauge length of $160 \mathrm{~mm}$ (including embedded distance of each jaw of the testing machine. Six tension coupons were tested in the tension test machine. We obtained the mechanical properties of flange and web steel by taking the average of the three results of flange steel coupons and the average of the three results of web steel coupons 
respectively. The obtained mechanical properties such as modulus of elasticity, elongation percentage, ultimate and yield stresses are listed in Table 3.

Table 1: Dimensions of tested cantilever girders with corrugated steel webs

\begin{tabular}{|c|c|c|c|c|c|c|c|}
\hline GIRDER & $\begin{array}{c}\text { Thickness } \\
\text { of web } \\
(\mathrm{mm})\end{array}$ & $\begin{array}{c}\mathrm{b} \\
(\mathrm{mm})\end{array}$ & $\begin{array}{c}\mathrm{d} \\
(\mathrm{mm})\end{array}$ & $\begin{array}{c}\mathrm{h}_{\mathrm{r}} \\
(\mathrm{mm})\end{array}$ & $\alpha$ & $\begin{array}{c}\mathrm{S} \\
(\mathrm{mm})\end{array}$ & $\begin{array}{c}\mathrm{C} \\
(\mathrm{mm})\end{array}$ \\
\hline $\mathrm{T}_{\mathrm{r} 1}$ & 1 & - & 21.2 & 21.2 & 45 & 60 & 42.2 \\
\hline $\mathrm{T}_{\mathrm{z} 1}$ & 1 & 30 & 24 & 18 & 37 & 120 & 108 \\
\hline $\mathrm{T}_{\mathrm{z} 2}$ & 1 & 30 & 15 & 26 & 60 & 120 & 90 \\
\hline
\end{tabular}

Table 2: Corrugation dimensions for tested cantilever girders.

\begin{tabular}{|c|c|c|c|c|c|c|c|c|c|c|}
\hline Girder & $\begin{array}{c}\mathrm{t}_{\mathrm{W}} \\
(\mathrm{mm})\end{array}$ & $\begin{array}{c}\mathrm{h}_{\mathrm{w}} \\
(\mathrm{mm})\end{array}$ & $\begin{array}{c}\mathrm{b} \\
(\mathrm{mm})\end{array}$ & $\begin{array}{c}\text { Cantil- } \\
\text { ever } \\
\mathrm{span} \\
\mathrm{a} \\
(\mathrm{mm})\end{array}$ & $\mathrm{h}_{\mathrm{w}} / \mathrm{t}_{\mathrm{w}}$ & $\mathrm{h}_{\mathrm{w}} / \mathrm{b}$ & $\mathrm{a} / \mathrm{h}_{\mathrm{w}}$ & $\begin{array}{c}\mathrm{b}_{\mathrm{f}} \\
(\mathrm{mm})\end{array}$ & $\begin{array}{c}\mathrm{t}_{\mathrm{f}} \\
(\mathrm{mm})\end{array}$ & $\begin{array}{c}\text { Intermediate } \\
\text { Span } \\
\mathrm{L}(\mathrm{mm})\end{array}$ \\
\hline $\mathrm{T}_{\mathrm{r} 1}$ & 1 & 250 & 30 & 233.2 & 250 & 8.33 & 0.93 & 100 & 8.8 & 508.8 \\
\hline $\mathrm{T}_{\mathrm{z} 1}$ & 1 & 250 & 30 & 260 & 250 & 8.33 & 1.04 & 100 & 6 & 430 \\
\hline $\mathrm{T}_{\mathrm{z} 2}$ & 1 & 250 & 30 & 260 & 250 & 8.33 & 1.04 & 100 & 6 & 430 \\
\hline
\end{tabular}

Table 3: Mechanical properties of specimens as obtained from tension test

\begin{tabular}{|c|c|c|c|c|}
\hline Coupon type & $\mathrm{F}_{\mathrm{y}}(\mathrm{T} / \mathrm{CM} 2)$ & $\mathrm{F}_{\mathrm{u}}(\mathrm{T} / \mathrm{CM} 2)$ & $\mathrm{E}(\mathrm{T} / \mathrm{CM} 2)$ & Elongation $\%$ \\
\hline Flange & 3.5 & 4.0 & 2000 & 20 \\
\hline Web & 3.5 & 4.0 & 2000 & 20 \\
\hline
\end{tabular}

\section{TEST LOADS}

In the steel construction laboratory, Faculty of Engineering, Assuit University, the specimens were loaded under 60 ton capacity rail way bars testing machine which attached to a computer control system in loading. The load was applied to the specimens as two equal end concentrated loads across the top flange over the two end stiffeners as shown in Fig.2

\section{TEST RESULTS}

All the three girders tested failed due to the buckling of the web and lack of rupture at its connection to the flanges as shown in photos .1,2,3, and 4 . The test results are given in Tables 4, and 5 .All three girders carried shear stress bigger than the shear yield stress and load has been increased to the max capacity at failure load then dropped suddenly. In $\mathrm{T}_{\mathrm{r} 1}$ girder the web locally buckled in the vicinity of the applied load at the center, followed by tearing at its connection to the flanges shown in photo 1 . The load versus deflection curves for all tests are similar except girder $\mathrm{T}_{\mathrm{z} 1}$, as observed from Fig.3. The load-carrying capacity drops at the failure load and the specimen exhibits some residual strength after failure. 


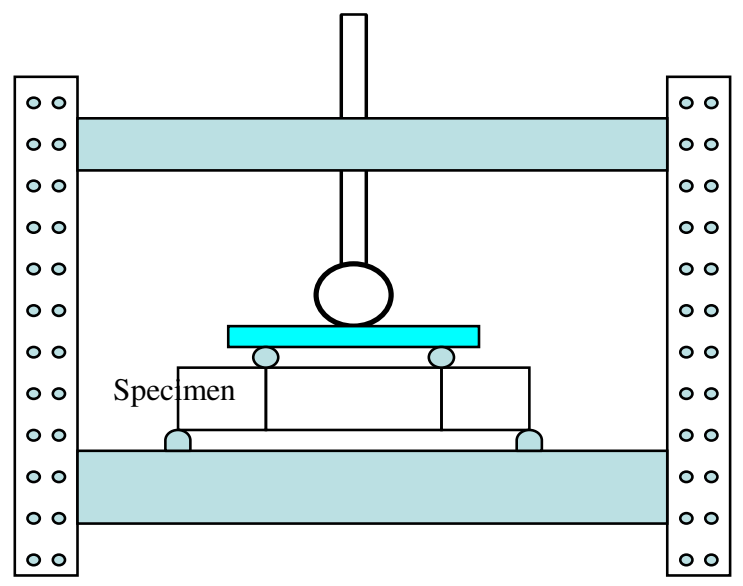

Fig.2. Test setup

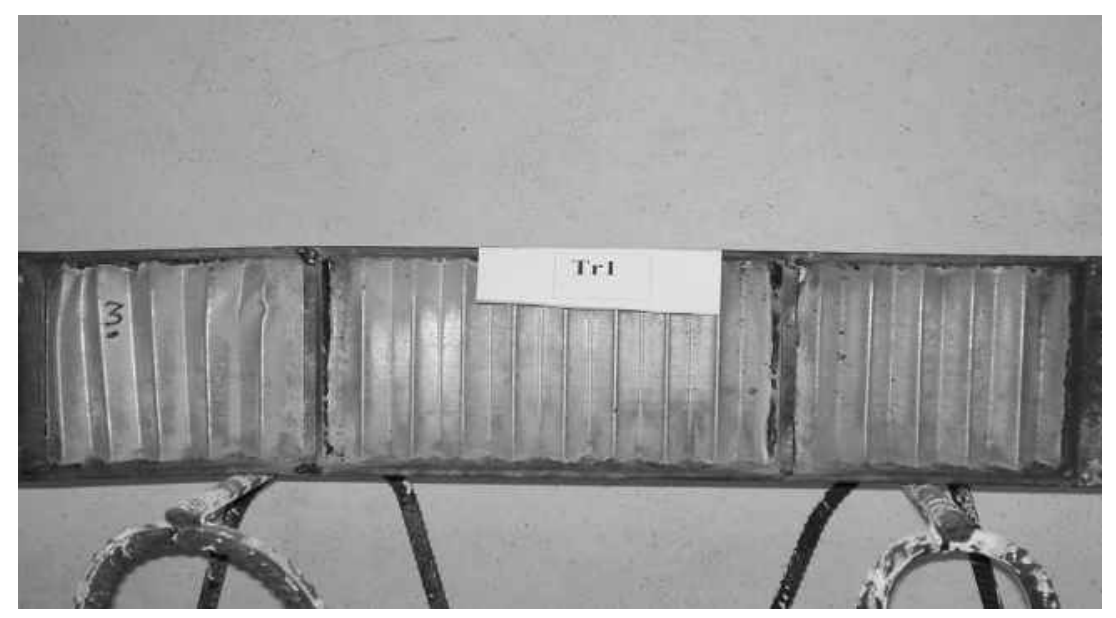

Photo 1: Failure mode of test specimen $T_{\text {r1 }}$

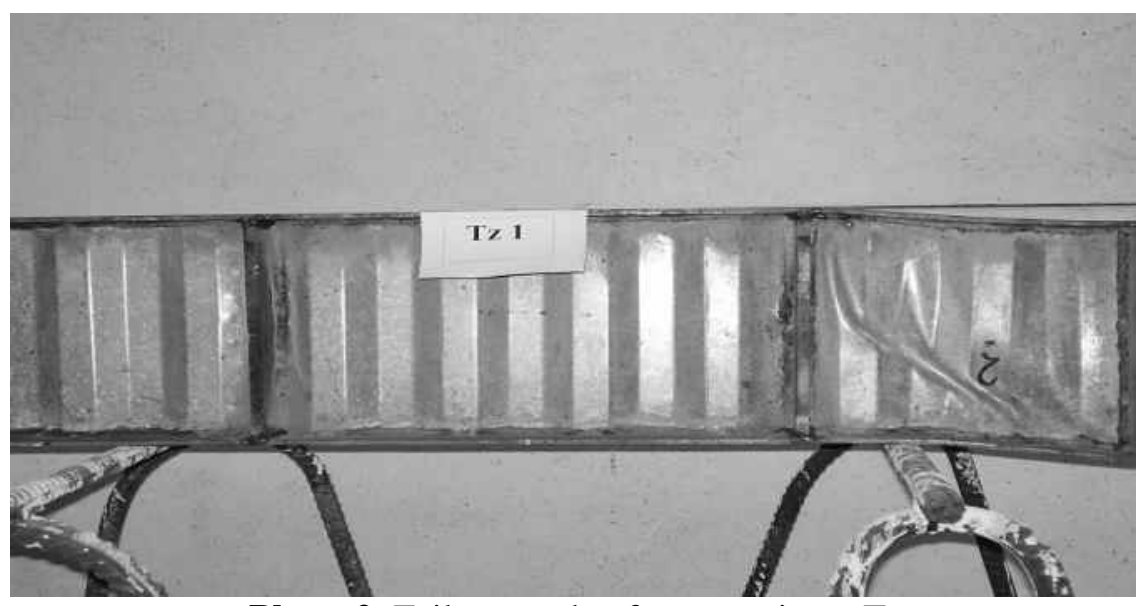

Photo 2: Failure mode of test specimen $\mathrm{T}_{\mathrm{Z} 1}$ 


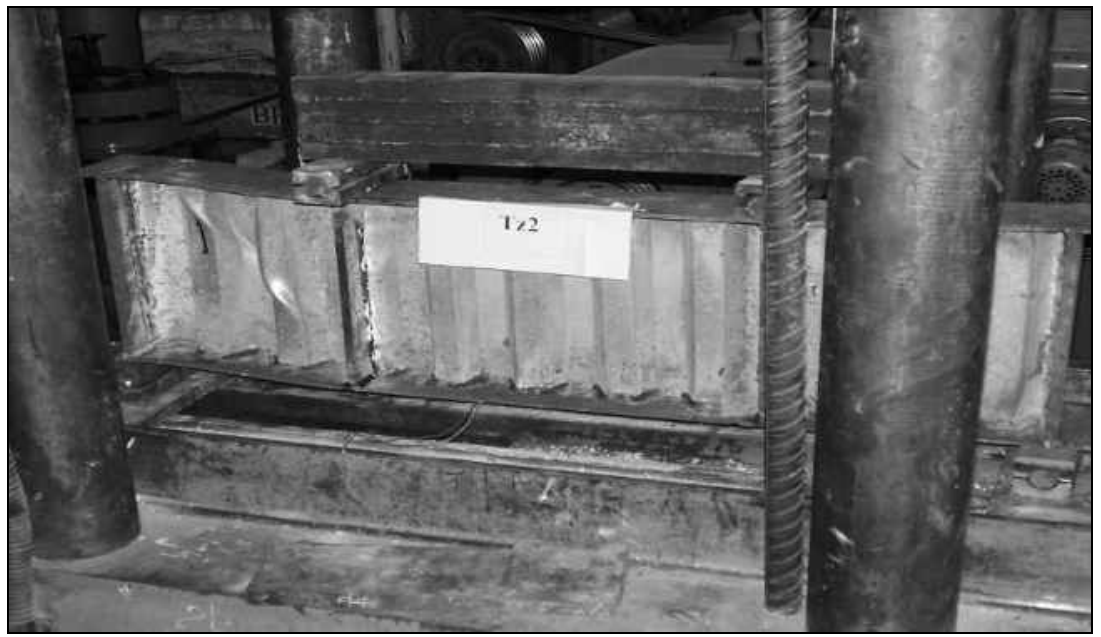

Photo 3: Failure mode of test specimen $\mathrm{T}_{\mathrm{z} 2}$ during test

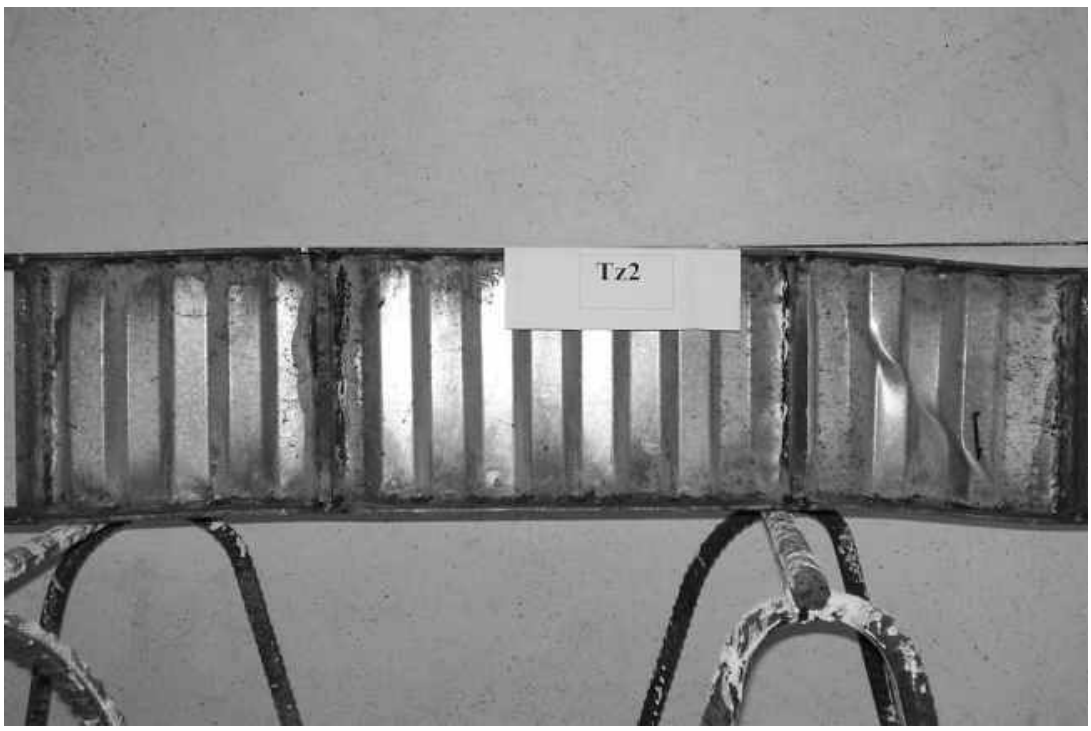

Photo 4: Failure mode of test specimen $\mathrm{T}_{\mathrm{Z}} 2$ after test 

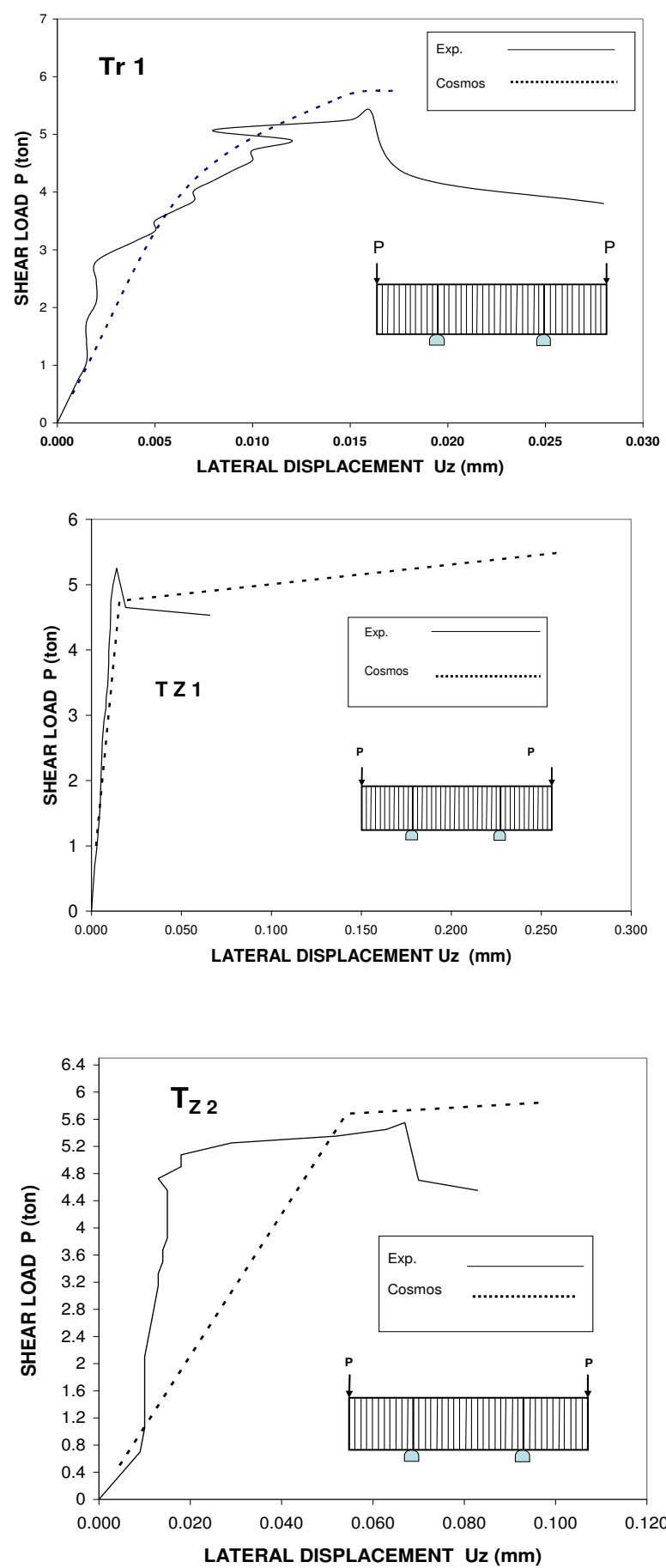

Fig.3: Shear load $\mathrm{p}$ (ton) versus lateral displacement (Uz $\mathrm{mm}$ ) for test specimens $\mathrm{T}_{\mathrm{r} 1}$, $\mathrm{T}_{\mathrm{z} 1}$ and $\mathrm{T}_{\mathrm{z} 2}$ till failure 


\section{FINITE ELEMENT ANALYSIS}

Due to the cost associated with testing and in order to study the effect of the corrugation configuration, the web panel aspect ratio and web-flange interaction on the ultimate shear capacity of the corrugated webs, one has to resort to numerical analysis using finite elements. If finite element models of the test specimens can depict the test results to reasonable degree of accuracy, the finite element method can be used to conduct parametric studies to understand the behavior of corrugated webs with variable dimensions under shear. Finite element analysis package COSMOS/M [15] was used to study the behavior of corrugated webs of the three test specimens under shear. We analyzed the full length of test specimens because the support conditions were not symmetrical. The boundary conditions were assumed such that all nodes in the shorter edge of the bottom flange at one support are fixed and all nodes in the other shorter edge of bottom flange at the other support are allowed to move only in the longitudinal direction. All other nodes at the two supports, such as that located in the web edge and the shorter edge of top flange were assumed to be restrained only in the lateral direction. All nodes in the four stiffener plates were also assumed to be restrained only in the lateral direction for all girders. A 4-node "QUAD4" thick shell finite element was used to model the flanges, stiffeners and web of the girders. Two elements across each fold of the corrugation web were used .Ten shell elements across the depth of the web and six shell elements across the flanges wide were used to keep the aspect ratio of the panel less than four. The typical finite element models generated are shown in Figs. 5, 11, and 14 for $\mathrm{T}_{\mathrm{z} 1}, \mathrm{~T}_{\mathrm{r} 1}$, and $\mathrm{T}_{\mathrm{z} 2}$ respectively. All geometry, boundary conditions, and loading were modeled in the Cartesian coordinate system. The flange and web steel properties were taken the same values that obtained from tension test of coupons, shown in Fig.4. Nonlinear static analysis was performed considering both geometric and material nonlinearties.The automatic increment of load scheme of COSMOS/M was employed and the solution was controlled with the arc length control to avoid the snap throw and the snap back of the curve.

\section{FINITE ELEMENT RESULTS}

The deformed shapes of three test specimens at failure are shown in figures 6,12 , and15. The shear load versus lateral deflection curves for the three test specimens are shown in Figures.8, 13, and 16.

In all girders the failure occurs at shear stress bigger than the shear yield stress then drop in curve happens as shown in figures 3 . The ultimate shear capacity from the finite element analysis and the test results are presented in Table4. As shown in this table, the agreement between the analytical and experimental results is satisfactory. The average ratio between the analytical and experimental results is 1.14 . The primary reason why the analytical results are higher than the experimental ones could be the presence of unavoidable out-of-plane initial imperfections in the test specimens. 

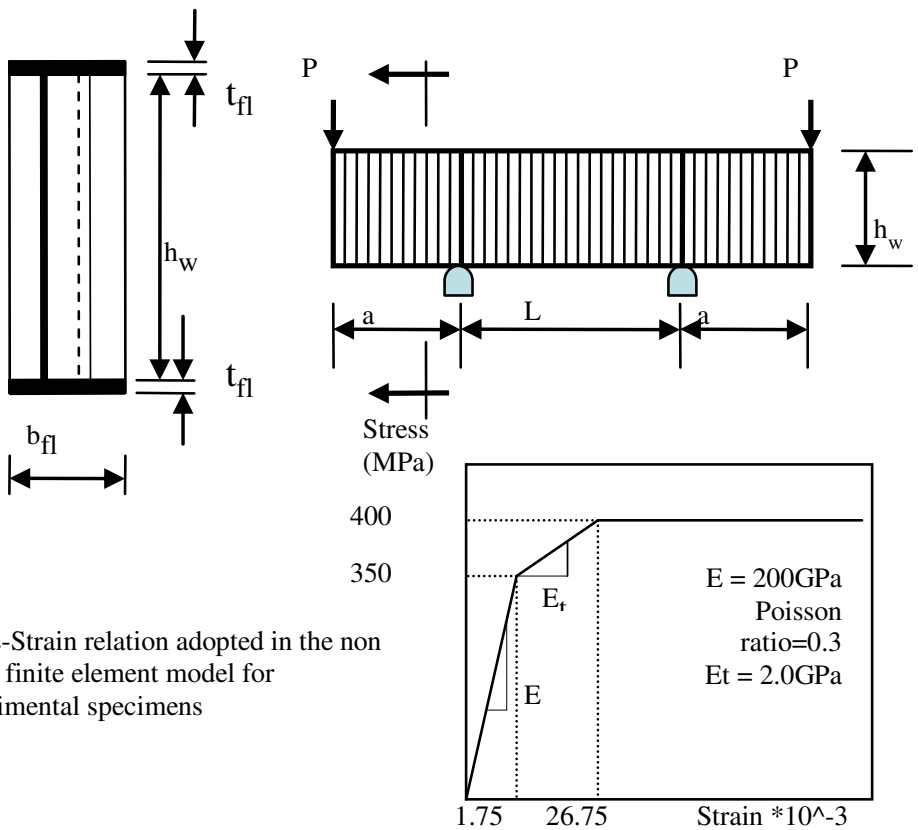

Fig.4: Analytical model for test specimens, loading and material properties

\section{SUMMARY AND CONCLUSION}

In this investigation, three steel cantilever beams with corrugated webs with different corrugation profiles and dimensions were studied experimentally and theoretically under the effect of shear load. The experimental work shows that the failure of all beams occurred due to shear buckling of the web without any interact of the flange. Finite element model was performed, using COSMOS/M package, to simulate the behavior of such beams theoretically. The results obtained from finite element analysis were compared with the experimental results. It is cleared that the finite element analysis results simulate the experimental results with a good degree of accuracy. So the finite-element model used here can be used with acceptable degree of accuracy to study the behavior of steel cantilever girders with corrugated webs with variable dimensions under shear. 


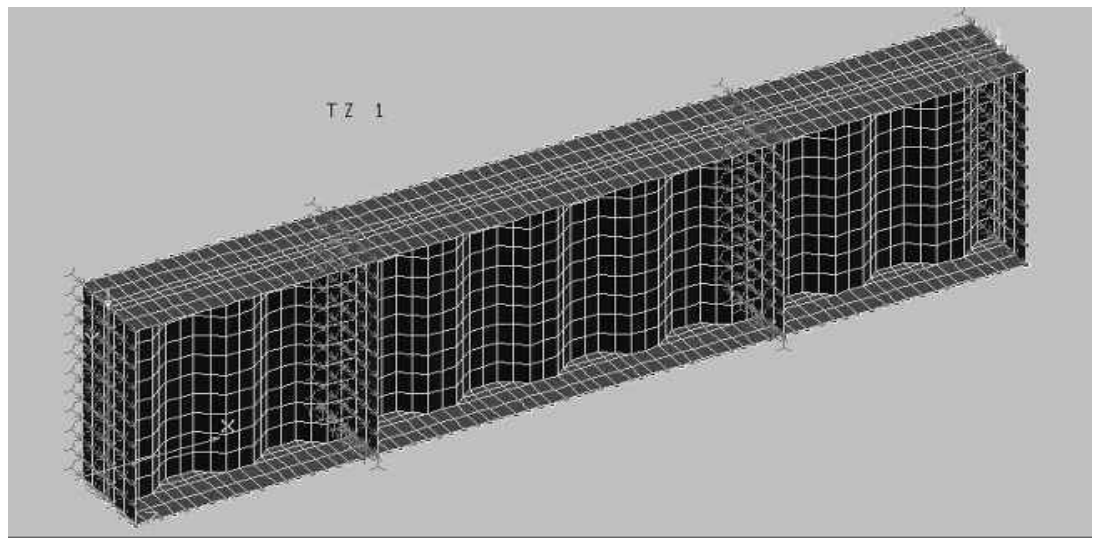

Fig.5: Finite element model for $\mathrm{T}_{\mathrm{z} 1}$, loads and boundary condition

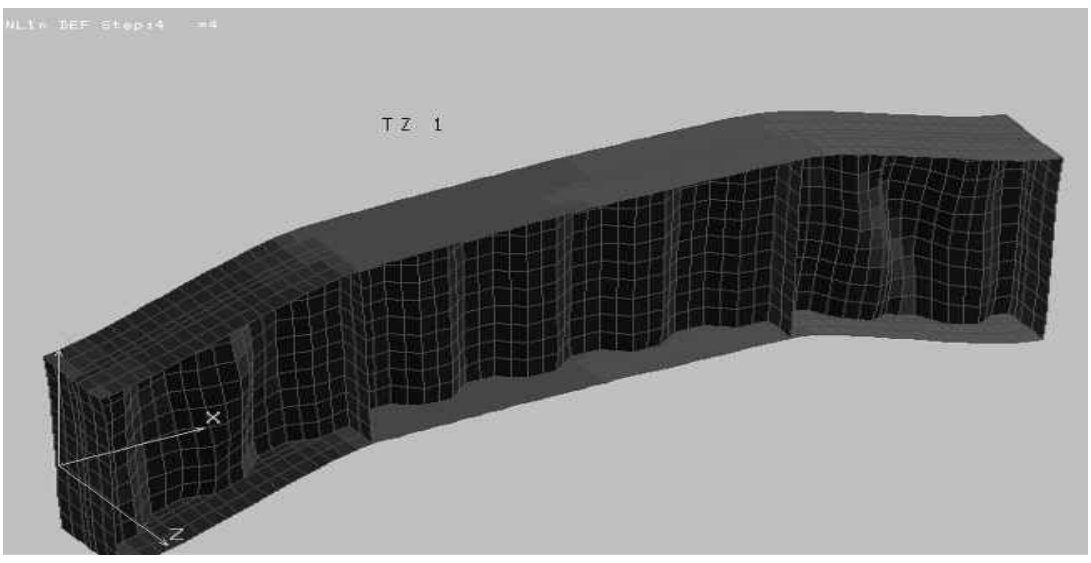

Fig.6: Deformed shape of $\mathrm{T}_{\mathrm{z} 1}$ at failure

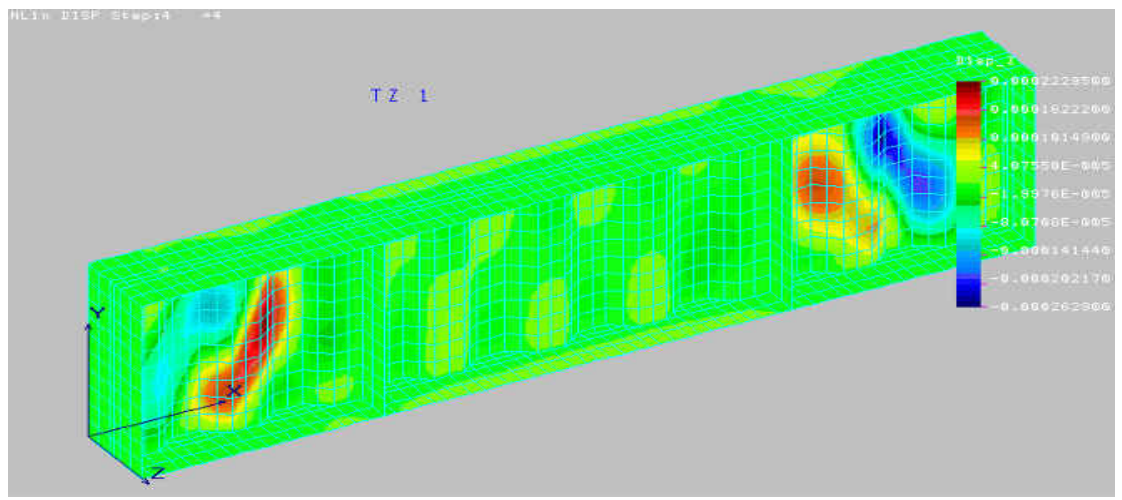

Fig.7: Lateral displacement distribution for $\mathrm{T}_{\mathrm{z} 1}$ at failure 


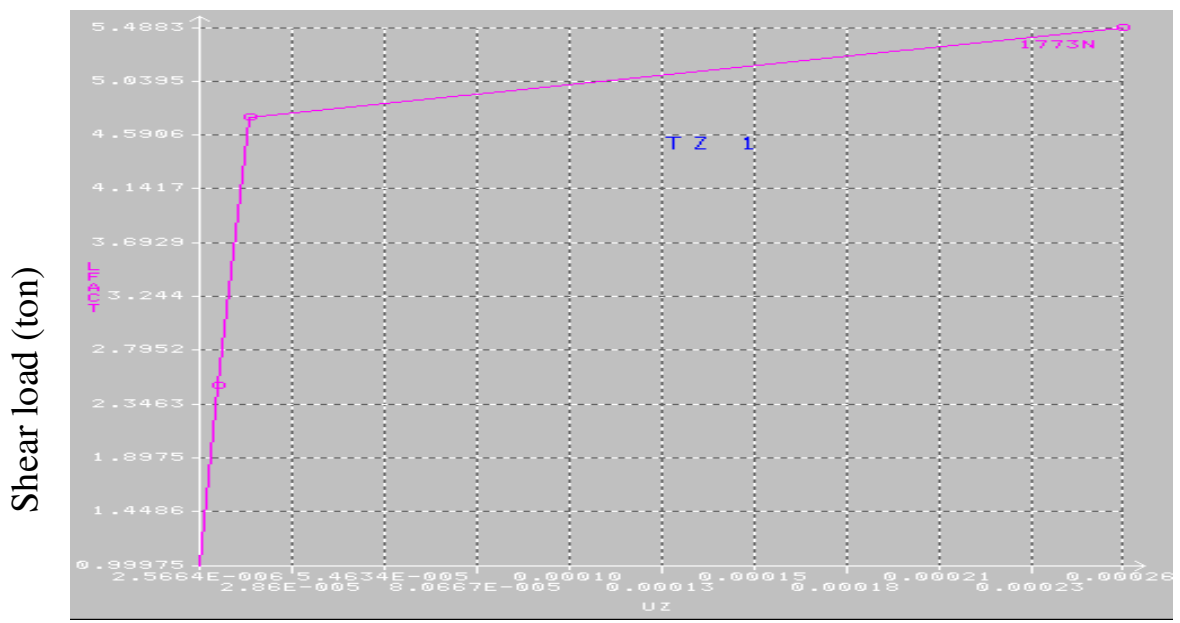

\section{Lateral displacement $\mathrm{Uz}$}

Fig.8: Shear load versus lateral displacement curve till failure for $T_{z 1}$

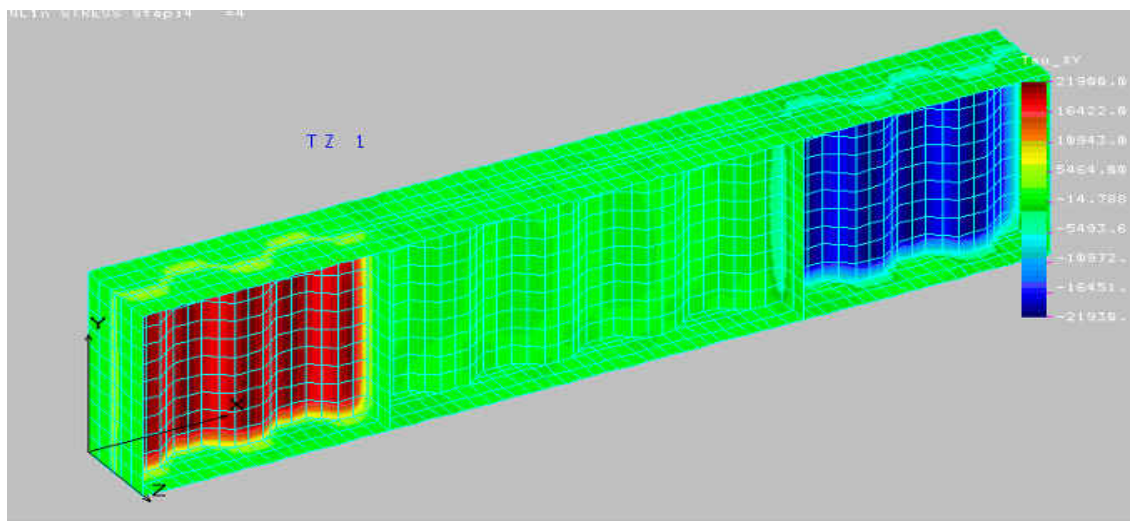

Fig.9: Shear stress distribution for $\mathrm{T}_{\mathrm{Z} 1}$ at failure

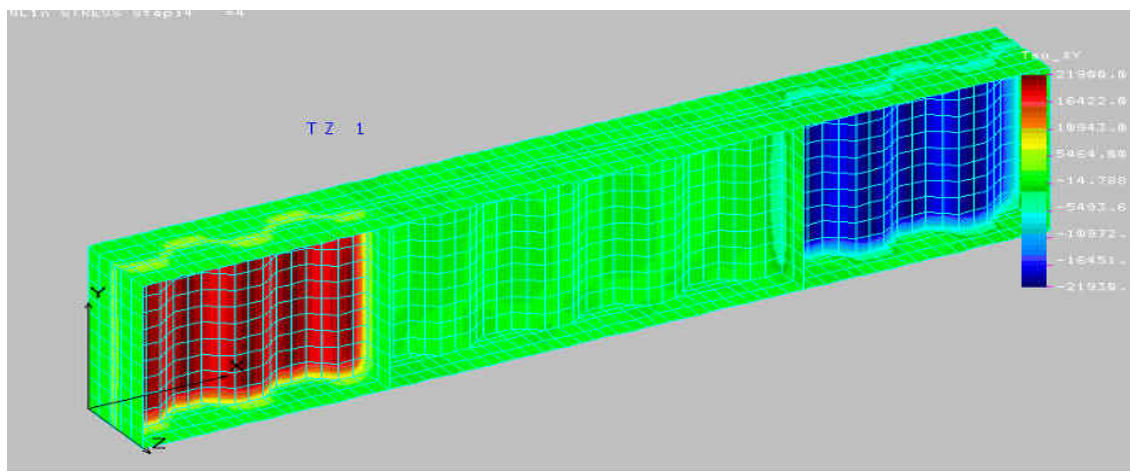

Fig.10: Von mises stress distribution for $\mathrm{T}_{\mathrm{z} 1}$ at failure 


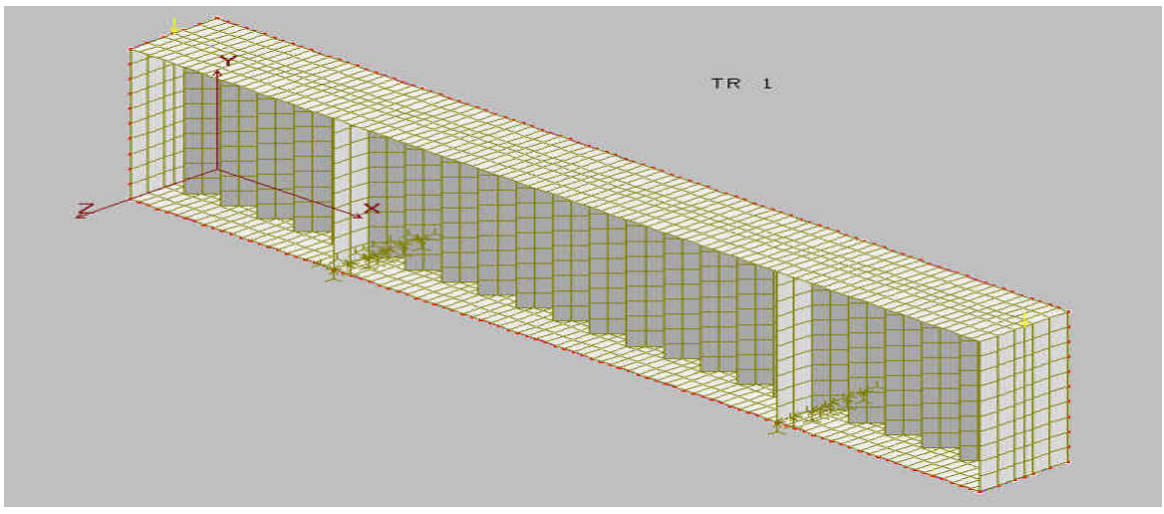

Fig. 11: Finite element model of $T_{r 1}$

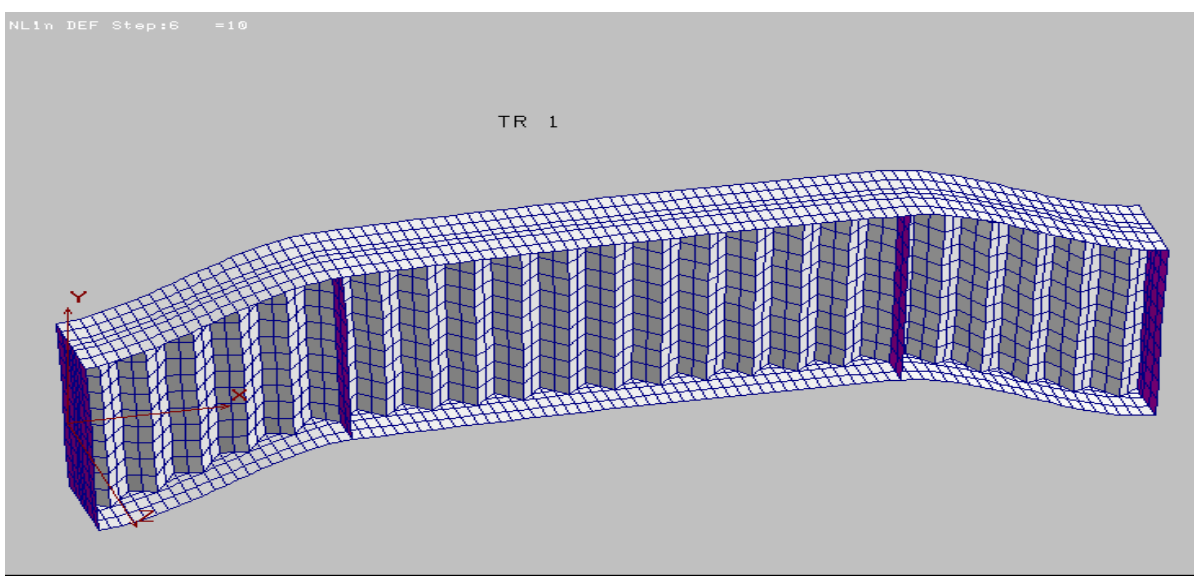

Fig.12: Deformed shape of $\mathrm{T}_{\mathrm{r} 1}$ at failure

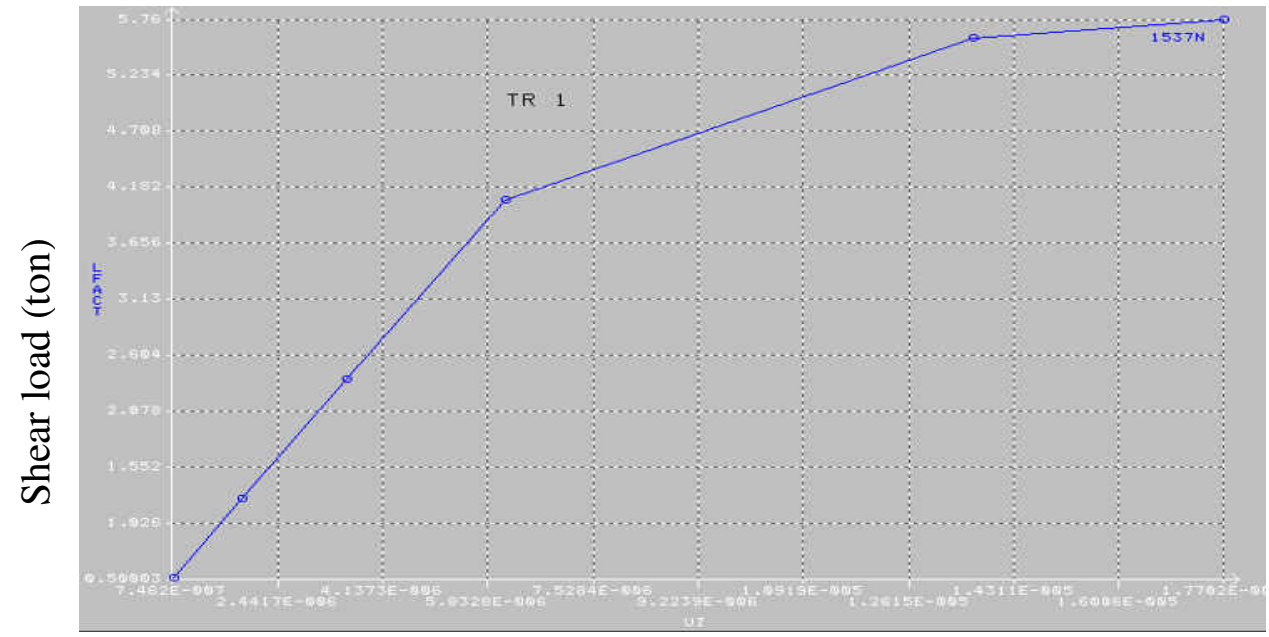

Lateral displacement $\mathrm{Uz}$

Fig.13: Shear load versus lateral displacement curve till failure for $T_{r 1}$ 


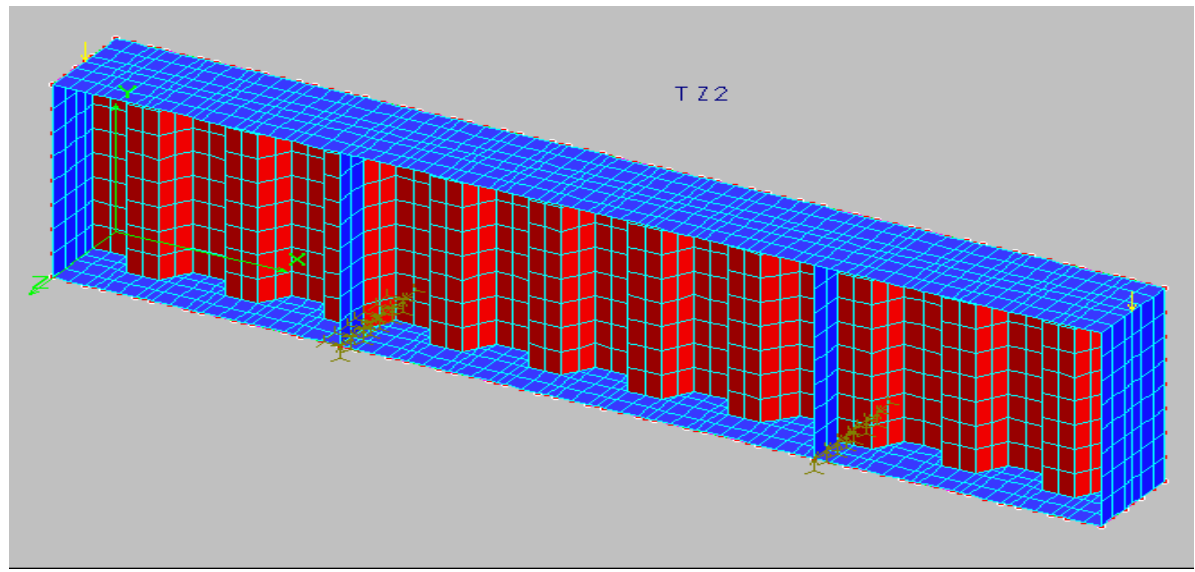

Fig. 14: Finite element model of $\mathrm{T}_{\mathrm{z} 2}$

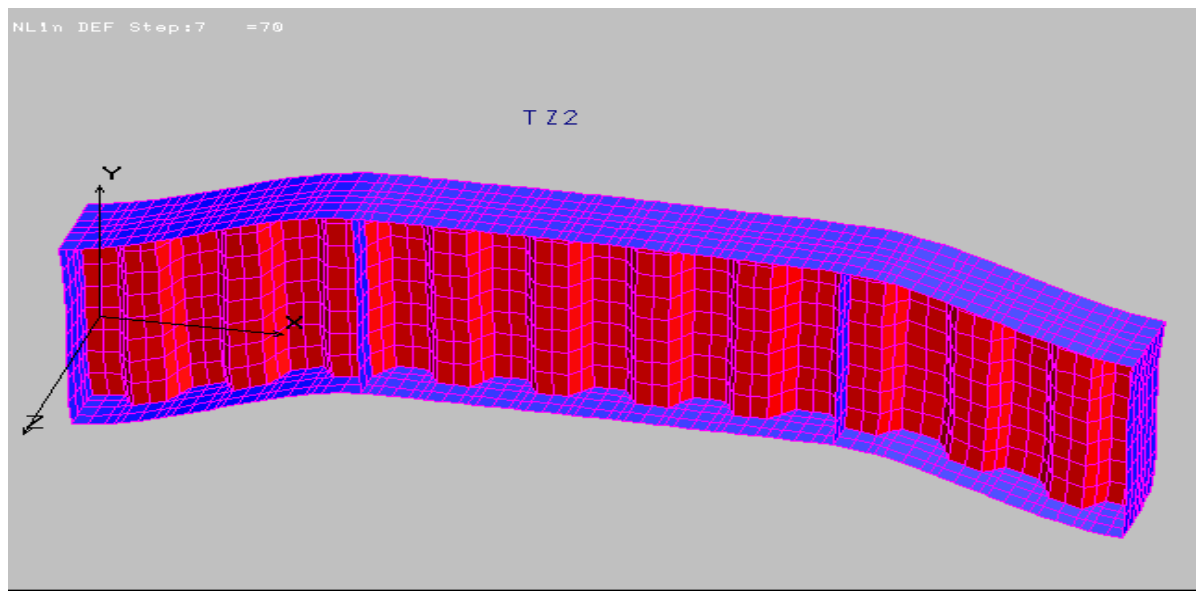

Fig.15: Deformed shape of $\mathrm{T}_{\mathrm{z} 2}$ at failure

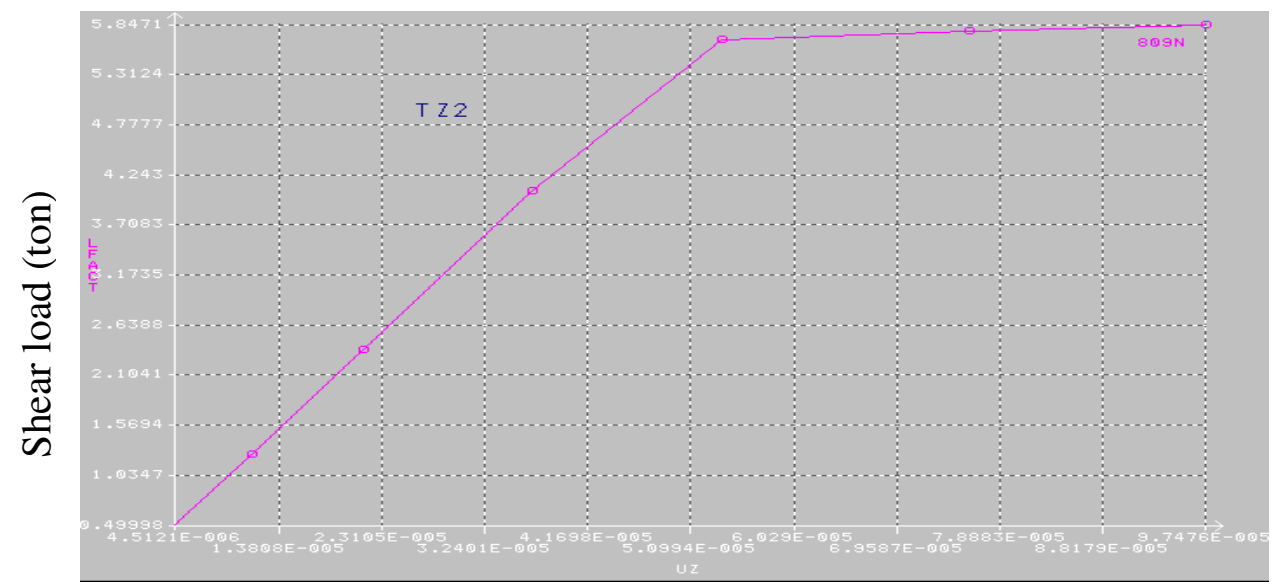

Lateral displacement $\mathrm{Uz}$

Fig.16: Shear load versus lateral displacement curve till failure for $\mathrm{T}_{\mathrm{z} 2}$ 


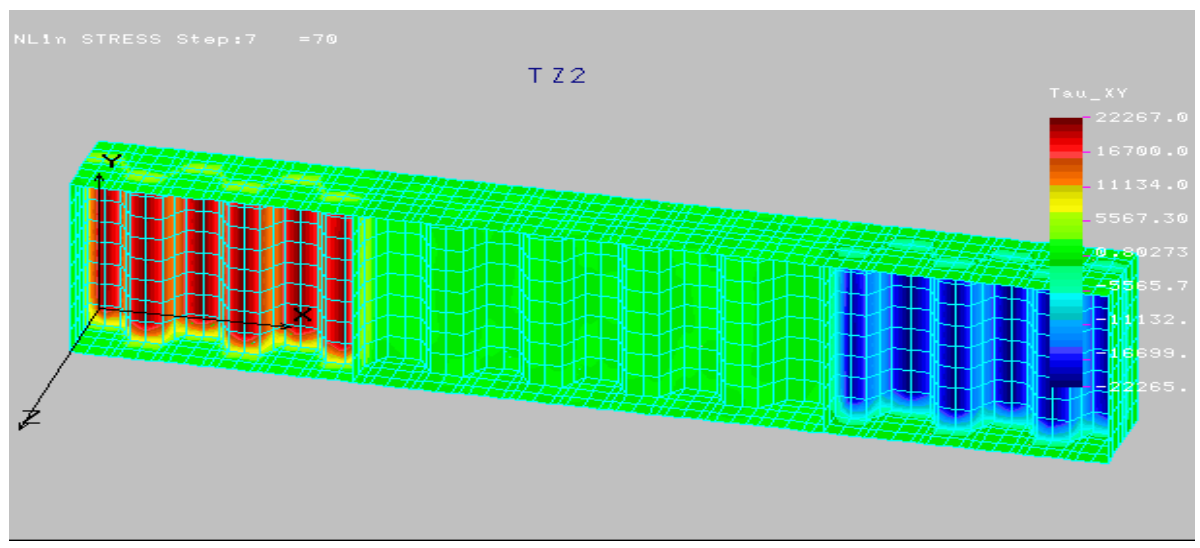

Fig.17: Shear stress distribution for $\mathrm{T}_{\mathrm{z} 2}$ at failure

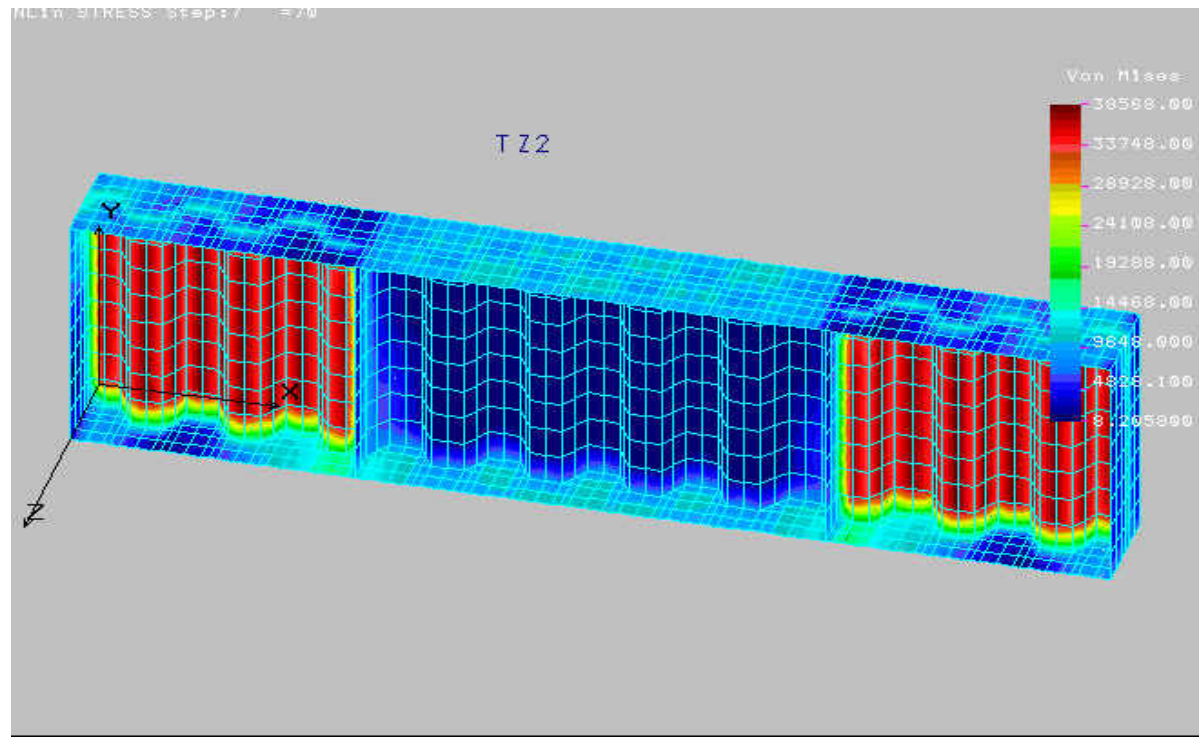

Fig.18: Von mises stress distribution for $\mathrm{T}_{\mathrm{z} 2}$ at failure

Table 4: Finite element versus test results at failure

\begin{tabular}{|c|c|c|c|}
\hline $\begin{array}{c}\text { GIRDER } \\
\text { no }\end{array}$ & $\begin{array}{c}\mathrm{P}_{\mathrm{f}} \\
\text { (ton) } \\
\text { at failure }\end{array}$ & $\begin{array}{c}\mathrm{P}_{\exp } \\
\text { (ton) } \\
\text { at failure }\end{array}$ & $\begin{array}{c}\mathrm{P}_{\mathrm{f}} / \mathrm{P}_{\text {exp }} \\
\text { at failure }\end{array}$ \\
\hline $\mathrm{T}_{\mathrm{r} 1}$ & 5.76 & 5.425 & 1.06 \\
\hline $\mathrm{T}_{\mathrm{z} 1}$ & 5.49 & 5.25 & 1.05 \\
\hline $\mathrm{T}_{\mathrm{z} 2}$ & 5.85 & 5.55 & 1.05 \\
\hline
\end{tabular}


Table 5: Shear stresses from test and finite element analysis versus shear yield stress

\begin{tabular}{|c|c|c|c|c|c|c|}
\hline $\begin{array}{c}\text { GIRDER } \\
\text { no }\end{array}$ & $\begin{array}{c}\tau_{\mathrm{f}} \\
(\mathrm{MPa})\end{array}$ & $\begin{array}{c}\tau_{\mathrm{y}}=\tau_{\mathrm{cr}} \\
(\mathrm{MPa})\end{array}$ & $\begin{array}{c}\tau_{\exp } \\
(\mathrm{MPa})\end{array}$ & $\tau_{\exp } / \tau_{\mathrm{cr}}$ & $\tau_{\mathrm{f}} / \tau_{\mathrm{cr}}$ & $\tau_{\mathrm{f}} / \tau_{\exp }$ \\
\hline $\mathrm{T}_{\mathrm{r} 1}$ & 230.4 & 202.07 & 217 & 1.108 & 1.14 & 1.06 \\
\hline $\mathrm{T}_{\mathrm{z} 1}$ & 219.6 & 202.07 & 210 & 1.039 & 1.087 & 1.046 \\
\hline $\mathrm{T}_{\mathrm{z} 2}$ & 234 & 202.07 & 222 & 1.099 & 1.158 & 1.054 \\
\hline
\end{tabular}

\section{REFERENCES}

1- Bleich, F., "Buckling Strength of Metal Structures" Mc Graw-Hill Book Co, New York (1952).

2- Basler,K., "Strength of Plate Girders in Shear" Journal of Structural Division, ASCE, Vol.87, No. ST 7, pp151-180, October, (1961).

3- Easley,J.T., and McFarland, D.E., "Buckling of Light-Gage Corrugated Metal Shear Diaphragms" Journal of Structural Division, ASCE, Vol.95, No. ST 7, pp1497-1516, July, (1969).

4- Bergman, V.S, and Reissner,H. ,"Neuere Problemme aus der Flugzeugstatik" Zeitschrift Flugtech und Mororluftsch,vol.20,(1929).

5- Hlavacek, V., discussion of "Buckling of Light-Gage Corrugated Metal Diaphragms." by John T.Easley and David E.McFarland, Journal of Structural Division, ASCE, Vol.96, No. ST 3, pp740-743, March, (1970).

6- Easley, J.T., "Buckling formulae for corrugated metal shear diaphragms" Journal of Structural Division, ASCE, Vol.101, No. ST 7, pp1403-1417, July, (1975).

7- Galambos, T.V., "Guide to Stability Design Criteria for Metal Structure" John Wiley and Sons, inc., New York, N.Y, (1988).

8- Bergfelt, A., and Leiva-Aravena, L., "Shear Buckling of Trapezoidal Corrugated Girders Webs" Report No. S 84:2, Dept. Of Struct. Eng, Chalmers Univ. of Technology, Gothenburg, Sweden, (1984).

9- Hamilton, r., "Behavior of Welded Girders with Corrugated Webs" PhD Thesis, Dept. of Civ. Eng., Univ. of Maine, Orono, Maine, (1993).

10- Elgaaly, M., Hamilton, R., and Seshadri, A., "Shear Strength of Beams with Corrugated Webs." Journal of Structural Division, ASCE, Vol.122, No. ST 4, pp390-398, April, (1996).

11- Elgaaly, M., Hamilton, R., and Seshadri,A, A., "Bending Strength of Beams with Corrugated Webs" Journal of Structural Division, ASCE, Vol.123, No. ST 6, pp772-782, June, (1996).

12- El-Metwally, A.S., and Loov, R.E.," Prestressed Composite Girders with Corrugated Steel Webs" Proceeding of the $5^{\text {th }}$ International Conference on Short and Medium Span Bridges (SMSB): Development in Short and Medium Span Bridge Engineering '98, pp.1175-1187, Calgary, Canada, (1998a).

13- El-Metwally, A.S. ,and Loov,R.E.," Composite Girders-High Strength Concrete Combined with Corrugated Steel Webs" Proceeding of The International Symposium on High Performance and Reactive Powder Concrete, Vol.1, pp.197215, Sherbrooke, Quebec, Canada, (1998 b). 
14- Sayed, E.Y., "Behavior of Steel and/or Composite Girders with Corrugated Steel Webs" Canadian Journal of Civil Engineering, CJCE, Vol.28, No.4, pp. 656-672, August, (2001).

15-COSMOS/M 2.8, "A computer program for nonlinear static and dynamic analysis" Structural Research and Analysis Corporation, California, USA, September (2002).

16-Egyptian Code of Practice for Steel Constructions and Bridges, Code No. 205 (2001).

\section{السلوك اللاخطى لكمرات الصلب الكابولية ذات العصب المموج}

يهدف البحث الى دراسة عملية ونظرية للسلوك اللاخطى لكمرات الصلب الكابولية ذات العصب المموج تحت تأثنير الأحمال حتى الانهيار . أولا الدراسـة العمليـة: تم دراسـة ثنلاث كمـرات صلب كابوليـة من النـاحيتين وذات عصب ممسوج, ببحر

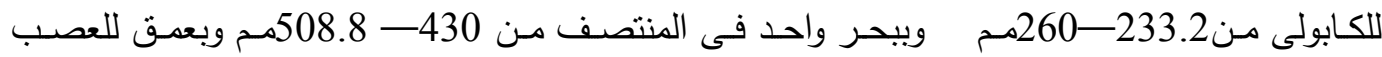

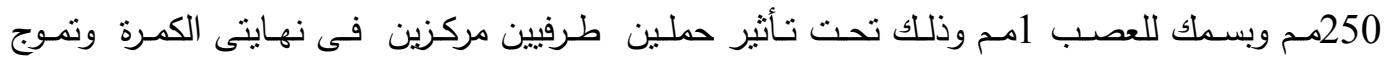
العصب فى كمرتين كان على هيئة أثنباه منحرفات وفى الكمرة الثالثة على هيئة مثلثات و ذلك للحصول على أقصى حمل انبعاجى للكمرات.

ثانيا الدراسة النظرية: تمت الدراسة بعمل نماذج نظرية للكمرات العملية الثلاثة بطريقة العناصر المحددة, وباستخدام التحليل ثلاثى الأبعاد اللاخطى بطريقة العناصر المحددة لتحديد الحمل الأقصى لتنالك الكمرات.

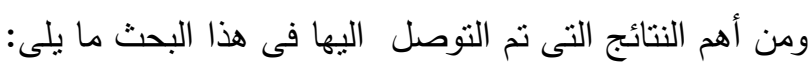

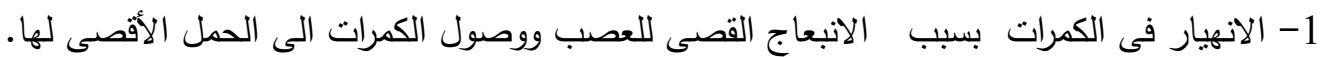
2-الحمل الأقصى لانهيار هذه الكمرات جميعا كان أكبر من الحمل الحرج النظرى المحسوب من مقاومة الخضوع القصية لهذة الكمرات. 3- بمقارنة النتائج النى حصلنا عليها عمليا ونظريا و نسبة الحمل الأقصى العملى لتحمل هذه الكمرات

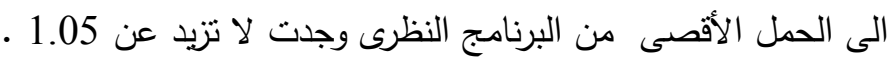

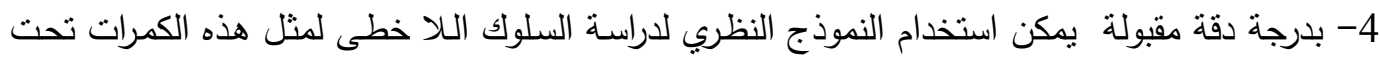

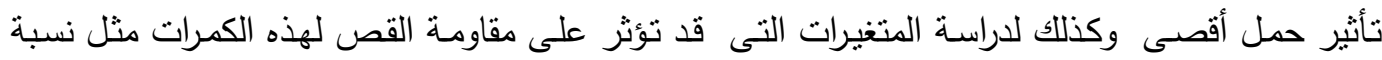
عق العصب الى سمكه و عرض التعرج للعصب وزاوية التعرج و شكل التعرج. 